\title{
Transcription of the tyrosinase gene in Streptomyces michiganensis DSM 40015 is induced by copper and repressed by ammonium
}

\author{
ThOMAS HELD* and HANS J. KUTZNER \\ Institut für Mikrobiologie, Technische Hochschule Darmstadt, Schnittspahnstr. 9, D-6100 Darmstadt, \\ Federal Republic of Germany
}

(Received 7 June 1990; revised 27 July 1990; accepted 24 August 1990)

\begin{abstract}
Induction of tyrosinase activity in the actinomycin producer Streptomyces michiganensis requires a medium low in ammonium and rich in copper ions. Copper is not only an essential part of the tyrosinase enzyme but it is also required for the induction of the gene at the level of transcription. Addition of copper, effective in both young and old cultures, specifically induces tyrosinase, which under optimal conditions may become the major newly synthesized protein. Ammonium represses tyrosinase formation at the level of transcription. Once repressed, tyrosinase biosynthesis cannot be induced by copper.
\end{abstract}

\section{Introduction}

Tyrosinase (EC 1.14.18.1) catalyses the oxidation of $L-$ tyrosine via L-dihydroxyphenylalanine (L-Dopa) to dopaquinone, which oxidizes spontaneously and polymerizes to form melanin. Many Streptomyces species have a tyrosinase gene but the functions of tyrosinase and melanin are unknown. In Streptomyces glaucescens the tyrosinase contains two copper atoms per molecule. Both copper atoms are bound to two histidine residues in the active centre of the enzyme and both are necessary for the activity of the enzyme (Huber \& Lerch, 1988). In $S$. glaucescens, tyrosinase activity can be induced by various amino acids, including L-methionine, L-leucine and Lphenylalanine, but not L-tyrosine (Baumann \& Kocher, 1976; Kieser et al., 1976), while the tyrosinase of Streptomyces antibioticus is induced at low effector concentrations only by L-methionine (Katz \& Betancourt, 1988).

According to Crameri et al. (1982) the tyrosinase of $S$. glaucescens first occurs cell-bound and is then released into the medium, where the formation of melanin takes place. The intracellular and extracellular forms of the enzyme are identical and consist of a single polypeptide chain of approximately $31 \mathrm{kDa}$ (Lerch \& Ettlinger, 1972; Huber et al., 1985). Surprisingly, no signal peptide sequence could be found in the tyrosinase structural gene. The DNA sequences coding for the tyrosinases of $S$. glaucescens (Huber et al., 1985) and S. antibioticus (Bernan et al., 1985) show $85.8 \%$ homology and the two protein sequences are $86.4 \%$ identical. Both the $S$. glaucescens and the $S$. antibioticus tyrosinase structural genes are preceded by very similar small open reading frames specifying proteins with amino-terminal signal peptides characteristic of exported proteins. Lee et al. (1988) showed that the upstream open reading frame $\left(\mathrm{ORF}_{438}\right)$ of $S$. antibioticus specifies a trans-acting factor which seems to facilitate the incorporation of copper into apotyrosinase.

In $S$. antibioticus (Katz \& Betancourt, 1988) and $S$. michiganensis (Platen \& Kutzner, 1986) the amount of active tyrosinase formed correlated with the concentration of copper added to the medium. In this paper we present evidence that the biosynthesis of the tyrosinase of $S$. michiganensis is induced by copper and repressed by ammonium.

\section{Methods}

\footnotetext{
Micro-organisms and cultivation. S. michiganensis DSM 40015 and its mutant derivatives were grown in a synthetic medium (SM) at $28^{\circ} \mathrm{C}$. SM contained, in $\mathrm{g}^{-1}$ : glycerol, 12.0 ; arginine. $\mathrm{HCl}, 5.0$; $\mathrm{MgSO}_{4} .7 \mathrm{H}_{2} \mathrm{O}, 0 \cdot 2 ; \mathrm{FeCl}_{3} .6 \mathrm{H}_{2} \mathrm{O}, 0.05 ; \mathrm{KH}_{2} \mathrm{PO}_{4}, 1 \cdot 0 ; \mathrm{K}_{2} \mathrm{HPO}_{4}, 1 \cdot 0$ trace element solution (without copper), $1.0 \mathrm{ml}$ (Drews, 1983); $\mathrm{pH} 7.2$. Copper $\left(\mathrm{CuSO}_{4}\right)$ was added at various times to a final concentration of $10^{-4} \mathrm{M}$. Solid media contained $12 \mathrm{~g}$ agar $\mathrm{1}^{-1}$. Tyrosine $\left(1.0 \mathrm{~g} \mathrm{t}^{-1}\right)$ was added for the detection of melanin formation. The complex medium (CM) used contained, in $\mathrm{g}^{-1}$ : glucose, $10 \cdot 0$; peptone, $5 \cdot 0$; meat extract, 5.0 ; yeast extract, $5.0 ; \mathrm{pH} \mathrm{7.2.}$

Cultures were grown in 1 litre Erlenmeyer flasks containing $400 \mathrm{ml}$ medium on a rotary shaker (170 r.p.m.). At appropriate time intervals samples were removed from the cultures to assay enzyme activities.

For radioactive labelling of proteins, ${ }^{[35}$ S methionine (specific
} 
activity $1000 \mathrm{Ci} \mathrm{mmol}^{-1} ; 37 \mathrm{TBq} \mathrm{mmol}^{-1}$ ) was added at the time of $\mathrm{Cu}^{2+}$ induction, to give $1.25 \mu \mathrm{Ci}$ per ml medium.

Reproducibility of results. The experiments were repeated twice and the mean results are shown.

Detection of actinomycin production. Plugs ( $6 \mathrm{~mm}$ diameter) were cut from 5-d-old SM agar cultures, transferred onto an agar plate (CM) confluently inoculated with Bacillus subtilis DSM 347, and incubated for $3 \mathrm{~h}$ at $4{ }^{\circ} \mathrm{C}$ and then overnight at $37^{\circ} \mathrm{C}$.

Preparation of crude cell extracts and culture filtrates. Cultures were harvested by centrifugation at $12000 \mathrm{~g}$ for $5 \mathrm{~min}$ at $4^{\circ} \mathrm{C}$ and the supernatant was used as culture filtrate for enzyme assays. The cells were washed once with $100 \mathrm{~mm}$-sodium phosphate buffer, pH 6.8, $5 \mathrm{~mm}$-EDTA and disrupted in the same buffer by sonication for $3 \mathrm{~min}$ (50\% intervals), $50 \mathrm{~W}$, at $0{ }^{\circ} \mathrm{C}$ using a Branson sonifier model 125 . Cell clebris was removed by centrifugation at $30000 \mathrm{~g}$ for $30 \mathrm{~min}$ at $4{ }^{\circ} \mathrm{C}$. The resulting supernatant was used as crude extract for enzyme assays. Protein concentrations in crude extracts and culture filtrates were cletermined by the method of Bradford (1976).

Determination of enzyme activities. Tyrosinase activity was measured polarographically with a YSI Biological Oxygen Monitor model 5300 (Jerumanis et al., 1976). The reaction was carried out in $2.5 \mathrm{ml} 0.1 \mathrm{M}$ sodium phosphate buffer, pH 6.8, $5 \mathrm{~mm}$-EDTA, with $1 \mathrm{~mm}-3,4-$ dihydroxy-L-phenylalanine as substrate. One nkat of tyrosinase activity is defined as the amount of enzyme causing the consumption of $1 \mathrm{nmol}$ $\mathrm{O}_{2} \mathrm{~s}^{-1}$.

Polyacrylamide gel electrophoresis. This was done according to Blackshear (1984), in $0.7 \mathrm{M}-\beta$-alanine buffer (adjusted with glacial acetic acid to $\mathrm{pH} 4.5$ ) at $4^{\circ} \mathrm{C}$. Bromophenol blue was used as the tracking dye. After electrophoresis, gels were stained for tyrosinase activity with an air-saturated 3,4-dihydroxy-L-phenylalanine solution ( $1 \mathrm{mM}$, in $0.5 \mathrm{M}$-sodium phosphate buffer, $\mathrm{pH} \mathrm{6.8)} \mathrm{for} 1 \mathrm{~h}$ at $28^{\circ} \mathrm{C}$. For autoradiography, gels were dried in a vacuum dryer $\left(2 \mathrm{~h}, 65^{\circ} \mathrm{C}\right)$ and exposed to Fuji RX X-Ray film for $10 \mathrm{~d}$ at $-80^{\circ} \mathrm{C}$.

Mutagenesis. $N$-Methyl- $N^{\prime}$-nitro- $N$-nitrosoguanidine (NTG) was added to a spore suspension $(1 \mathrm{ml})$ in Tris/maleic acid buffer, $50 \mathrm{~mm}$, $\mathrm{pH} \mathrm{9.0,} \mathrm{to} \mathrm{a} \mathrm{final} \mathrm{concentration} \mathrm{of} 1 \mathrm{mg} \mathrm{ml}^{-1}$. After incubation for $1 \mathrm{~h}$ at $28^{\circ} \mathrm{C}$, the spores were washed once and appropriate dilutions were plated on solid media.

DNA and RNA manipulations. Plasmid DNA and total DNA from $S$. michiganensis were prepared as described by Hopwood et al. (1985). RNA was isolated according to Chirgwin et al. (1979). Plasmids from E. coli were isolated by the method of Birnboim \& Doly (1979). Restriction analysis was done according to Fuchs \& Blakesley (1983) with enzymes from Gibco-BRL. For ligation, transformation and agarose gel electrophoresis of DNA the methods described by Maniatis et al. (1982) were used.

Construction of hybridization probes. A series of probes were constructed (Fig. 1) which were used for two purposes: (a) hybridization of pTH-cif (cif = copper incorporation factor) with total DNA of $S$. michiganensis to prove the existence of a gene related to the $\mathrm{ORF}_{438}$ of $S$. antibioticus; (b) RNA dot-blot hybridization to examine copper induction at the level of transcription.

The $1.56 \mathrm{~kb} \mathrm{Bcll}$ fragment of pIJ702 (Katz et al., 1983) containing the $S$. antibioticus mel operon was cloned into the BamHI site located on the polylinker of the E. coli vector pUC19 (Yanisch-Perron et al., 1985), to form pTH-mel.

pTH-cif was constructed by digestion of pTH-mel with SalI and religation. This probe contains $399 \mathrm{bp}$ of $\mathrm{ORF}_{438}$ and completely lacks the tyrosinase structural gene.

pTH-tyr consists of the pUC19 vector with the $0.26 \mathrm{~kb}$ Sall fragment

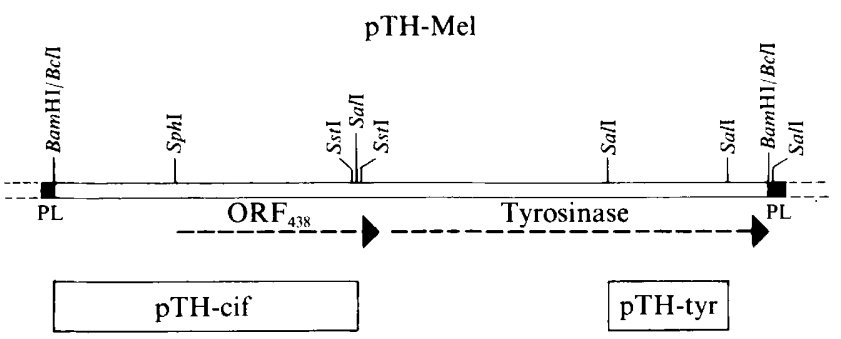

Fig. 1. Hybridization probes pTH-mel, pTH-cif and pTH-tyr. The probes were constructed by successive subcloning in pUC19 of the $1.56 \mathrm{~kb} \mathrm{BclI}$ mel fragment of $S$. antibioticus, isolated from the plasmid pIJ702. PL, polylinker of pUC19 (for details see Methods).

of the tyrosinase structural gene inserted into the single $S a$ II site of the polylinker. This fragment contains the His-190 codon of the $S$. antibioticus tyrosinase which is probably responsible for the binding of the copper. In the tyrosinase of $S$. glaucescens the His-189 residue was proved to be a ligand of this metal (Huber \& Lerch, 1988).

Hybridization studies. The RNA or denatured DNA $\left(100^{\circ} \mathrm{C}, 10 \mathrm{~min}\right)$ was dotted onto nitrocellulose equilibrated with $20 \times \operatorname{SSC}(3.0 \mathrm{M}$ $\mathrm{NaCl}, 0.3 \mathrm{M}$-trisodium citrate) or $2 \times \mathrm{SSC}$, respectively. After baking of the filter $\left(2 \mathrm{~h}, 80^{\circ} \mathrm{C}\right)$, prehybridization was carried out for $6 \mathrm{~h}$ at $42{ }^{\circ} \mathrm{C}$ in the following solution: $50 \%(\mathrm{v} / \mathrm{v})$ formamide, $5 \times \mathrm{SSC}, 5 \times$ Denhardt's solution $[0 \cdot 1 \%(\mathrm{w} / \mathrm{v})$ Ficoll, $0 \cdot 1 \%(\mathrm{w} / \mathrm{v})$ polyvinylpyrrolidone, $0 \cdot 1 \%(\mathrm{w} / \mathrm{v})$ bovine serum albumin], $25 \mathrm{~mm}$-sodium phosphate, $\mathrm{pH} 6.5$, and $0.5 \mathrm{mg} \mathrm{ml}^{-1}$ freshly heat denatured yeast tRNA (10 min, $100{ }^{\circ} \mathrm{C}$ ). Hybridization was carried out in $45 \%$ formamide, $5 \times \mathrm{SSC}$, $1 \times$ Denhardt's solution, $20 \mathrm{~mm}$-sodium phosphate, pH $6.5,0.2 \mathrm{mg}$ $\mathrm{ml}^{-1}$ yeast tRNA, 4\% dextran sulphate and the labelled DNA-probe. Nick-translation was done as described by Hopwood et al. (1985) using biotin-11-dUTP (Gibco-BRL). After hybridization $\left(37^{\circ} \mathrm{C}\right.$, overnight) the filter was consecutively washed with $2 \times$ SSC $+0.1 \%$ SDS $(2 \times 3 \mathrm{~min}) ; \quad 0.2 \times \mathrm{SSC}+0.1 \%$ SDS $(2 \times 3 \mathrm{~min}) ; 0.063 \times$ $\mathrm{SSC}+0.1 \% \mathrm{SDS}\left(2 \times 15 \mathrm{~min}, 50^{\circ} \mathrm{C}\right)$ and finally with $0.1 \mathrm{M}-\mathrm{Tris} / \mathrm{HCl}$, pH $7.5,3 \%$ bovine serum albumin, $460 \mathrm{~mm}-\mathrm{NaCl}$. The biotinylated DNA was detected using the 'ENZO DETEK I alk' system (Ortho Diagnostic Systems).

\section{Results}

Influence of various copper concentrations on activity of tyrosinase in the medium

As shown in Fig. 2, a positive correlation between addition of copper to the medium and the activity of tyrosinase could be demonstrated. The control culture with no copper added showed only a very small peak of tyrosinase activity at the beginning of the exponential phase, which was presumably due to small amounts of copper contaminating the components of the medium (Platen \& Kutzner, 1986). While the addition of $10^{-7} \mathrm{M}^{-}$ $\mathrm{CuSO}_{4}$ did not result in increased tyrosinase activity, higher concentrations $\left(5 \times 10^{-6} \mathrm{M}\right.$ and $\left.10^{-4} \mathrm{M}\right)$ led to a dramatic increase of enzyme activity. Growth was

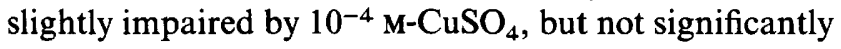
influenced by the other copper concentrations used. 


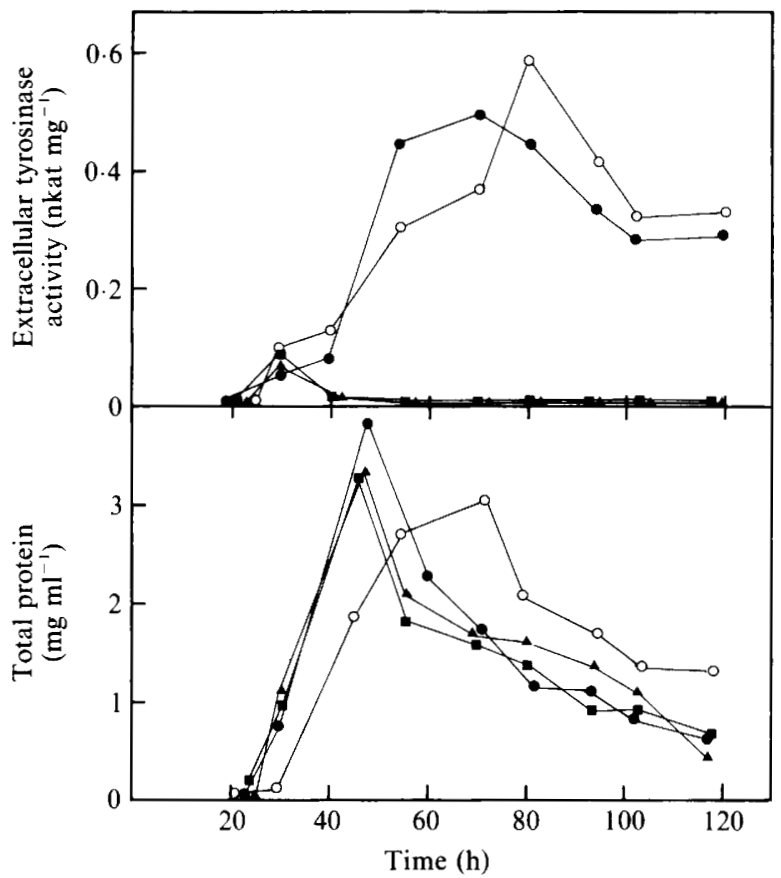

Fig. 2. Influence of various copper concentrations on activity of tyrosinase in the medium. $\square$, No copper added; $\Delta, 10^{-7} \mathrm{M}-\mathrm{CuSO}_{4} ; \bullet$, $5 \times 10^{-6} \mathrm{M}^{-} \mathrm{CuSO}_{4} ; \mathrm{O}, 10^{-4} \mathrm{M}^{-} \mathrm{CuSO}_{4}$.

\section{Addition of copper at various growth phases}

The kinetics of tyrosinase formation and of growth as influenced by the addition of copper at three different times during the early and late growth phase is shown in Fig. 3. Without addition of copper, low tyrosinase activity (as shown in Fig. 2) was formed. The addition of copper at 20,30 or $47 \mathrm{~h}$ after inoculation resulted in an increase in both cell-bound and extracellular tyrosinase activity within about $1 \mathrm{~h}$. In the case of copper addition in the late growth phase $(47 \mathrm{~h})$, a short time after copper supplementation the cells began to produce active cellbound enzyme, which was later released into the medium. The production rate was apparently higher than the excretion rate, resulting in cell-bound tyrosinase showing a peak about $5 \mathrm{~h}$ after copper addition.

The following experiments proved that the effects seen in Figs 2 and 3 were due to an induction of the tyrosinase by copper and not simply due to incorporation of copper in a preformed apotyrosinase.

\section{Absence of in vitro activation of an apotyrosinase by copper}

Crude cell extracts and culture filtrates were prepared from cultures without added copper, at times corresponding to the highest cell-bound $(52 \mathrm{~h})$ and extracellular $(90 \mathrm{~h})$ tyrosinase activities of copper-induced cul-

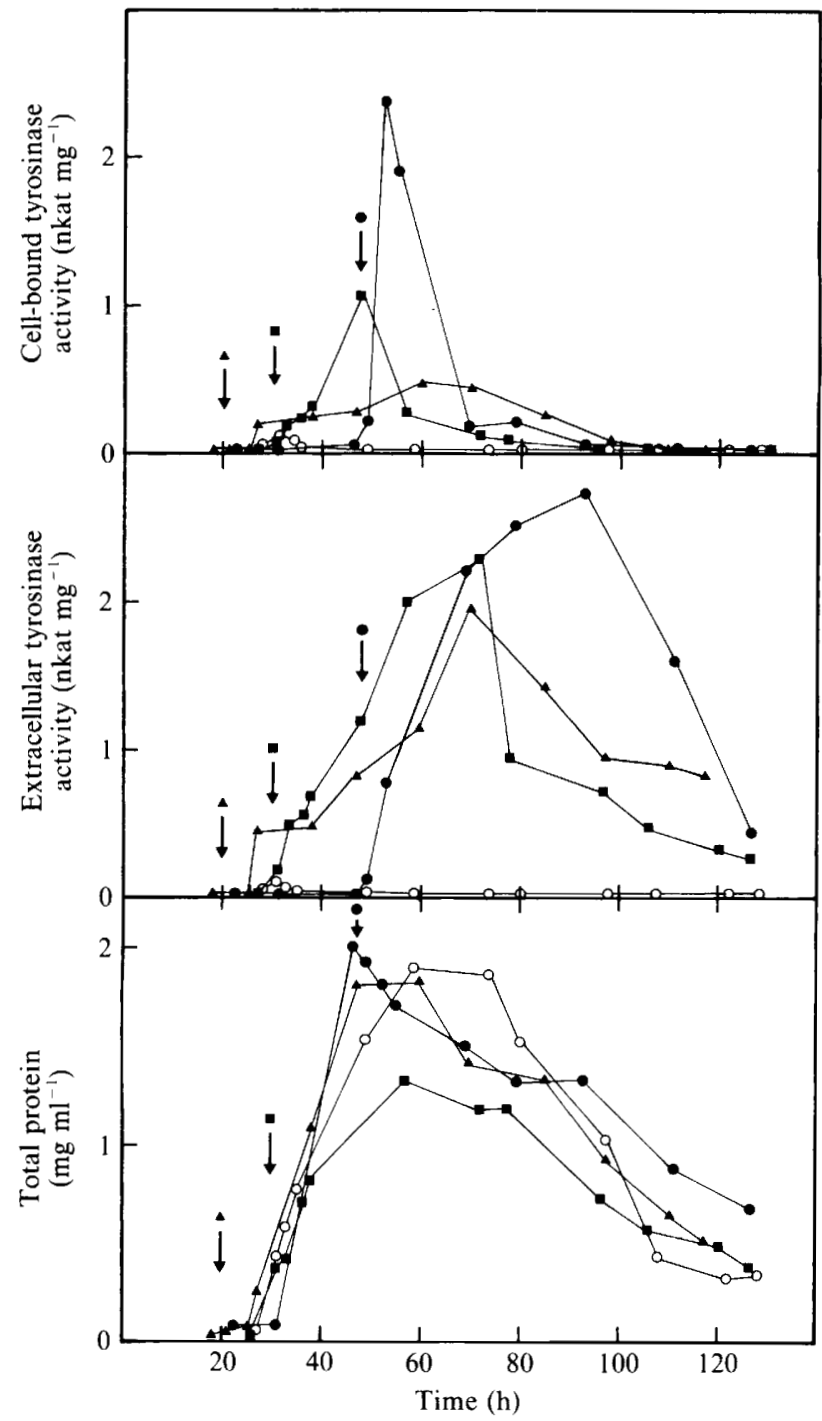

Fig. 3. Tyrosinase activity and growth after addition of copper at various phases of growth. $\mathrm{CuSO}_{4}$ was added to a final concentration of $10^{-4} \mathrm{M}$ at the times indicated. $\bigcirc$, Control without copper; $\Delta$, copper addition after $20 \mathrm{~h} ; \boldsymbol{\square}$, copper addition after $30 \mathrm{~h} ; \bullet$, copper addition after $47 \mathrm{~h}$.

tures. The crude extracts and culture filtrates were supplemented with $\mathrm{CuSO}_{4}\left(10^{-4} \mathrm{M}\right.$, final concn) and incubated for $0,30,60,90,120$ and $180 \mathrm{~min}$ at $28^{\circ} \mathrm{C}$. The addition of $\mathrm{Cu}^{2+}$ to these samples did not result in the formation of any enzyme activity.

\section{Inhibition of enzyme induction by chloramphenicol}

When chloramphenicol was added to a 47-h-old culture at the same time as $\mathrm{Cu}^{2+}$ no tyrosinase could be detected, whereas the control culture (without chloramphenicol) showed the expected production of tyrosinase (Fig. 4). Addition of chloramphenicol $3.5 \mathrm{~h}$ after the addition of 
$\mathrm{Cu}^{2+}$ stopped further enzyme producton and resulted in a slow decrease of cell-bound enzyme activity. These effects suggest that copper induces de novo synthesis of tyrosinase.

\section{$\left[{ }^{35} S\right]$ Methionine labelling of proteins at the time of copper induction}

$\left[{ }^{35}\right.$ S]Methionine was used for labelling for two reasons: (i) methionine does not induce the tyrosinase of $S$.

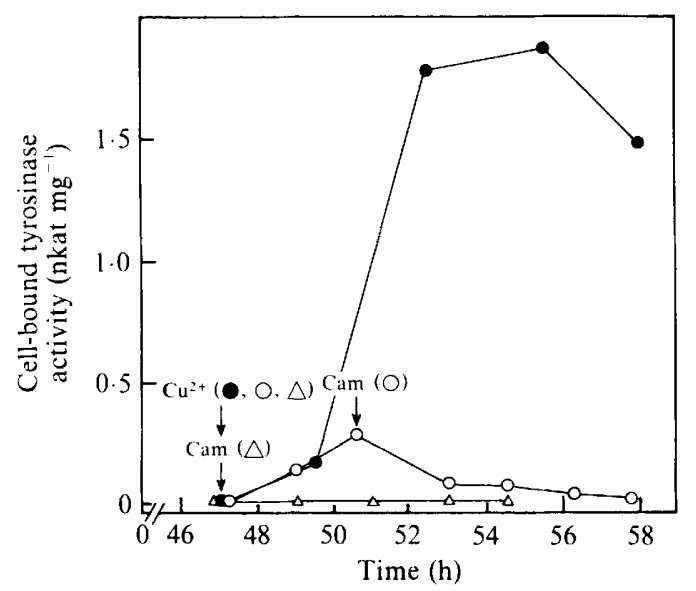

Fig. 4. Tyrosinase activity after inhibition of protein biosynthesis by chloramphenicol (Cam; $50 \mathrm{mg} \mathrm{l}^{-1}$, final concn) and induction with copper $\left(10^{-4} \mathrm{M}\right.$, final concn). michiganensis, in contrast to the enzyme of $S$. glaucescens (Baumann \& Kocher, 1976) and S. antibioticus (Katz \& Betancourt, 1988); (ii) the tyrosinases of the latter two species contain five methionine residues per molecule (Huber et al., 1985; Bernan et al., 1985). Since the tyrosinase of $S$. michiganensis is a basic protein with a $\mathrm{pI}$ of 9.0 (data not shown), the crude extracts from copperinduced and non-induced cultures were electrophoresed in an acidic gel ( $\mathrm{pH} 4.5)$. The tyrosinase band was localized by activity staining (Fig. $5 b, c$ ). The autoradiography of this gel exhibited a signal for tyrosinase in the copper-induced samples (Fig. $5 e$ ) but not in the controls (Fig. $5 d$ ).

\section{Repression of tyrosinase formation by ammonium}

Experiments with various media revealed that on minimal medium containing $\mathrm{NH}_{4} \mathrm{Cl}\left(1 \mathrm{~g} \mathrm{l}^{-1}\right)$ as nitrogen source no formation of melanin or of the antibiotic actinomycin occurred. On the other hand, the amino acids arginine, glutamine, aspartic acid and asparagine ( $5 \mathrm{~g} \mathrm{l}^{-1}$ each), and also $\mathrm{KNO}_{3}$ and urea $\left(\mathrm{g} \mathrm{l}^{-1}\right.$ each), allowed the formation of both melanin and actinomycin. These results suggest that both tyrosinase and actinomycin production are repressed by ammonium.

\section{Reversal of ammonium repression}

Three cultures grown with $\mathrm{NH}_{4} \mathrm{Cl}$ as nitrogen source were treated as shown in Fig. 6. While the addition of (a)

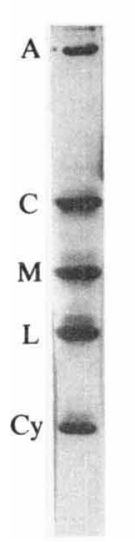

(b)

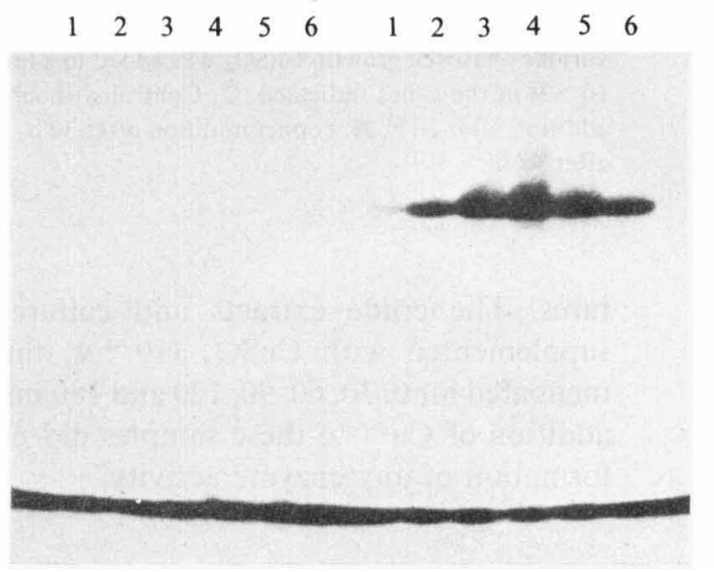

(d)

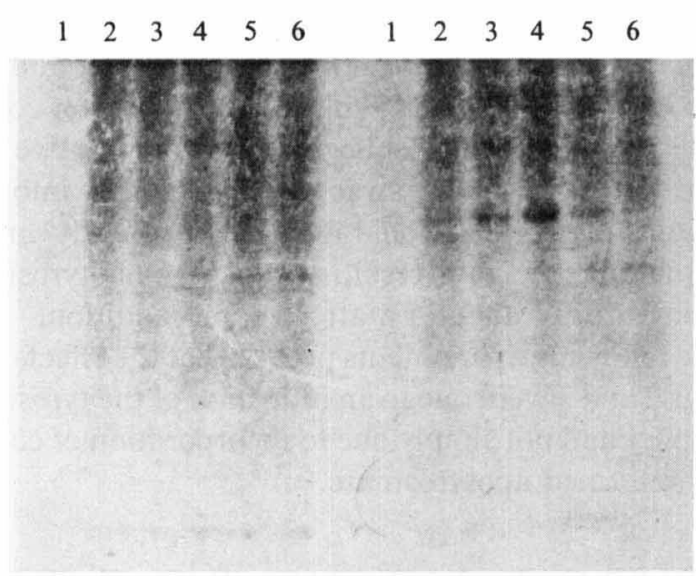

Fig. 5. $\left[{ }^{35} \mathrm{~S}\right]$ Methionine labelling of proteins in $S$. michiganensis. (a) Standard proteins (A, aldolase, $149.0 \mathrm{kDa}, \mathrm{pI} 8.4$; C, chymotrypsinogen, $25.5 \mathrm{kDa}$, pI 9.2; M, myoglobin, $17.8 \mathrm{kDa}, \mathrm{pI} 7.0 ; \mathrm{L}$, lysozyme, $13.9 \mathrm{kDa}, \mathrm{pI} 11.0 ; \mathrm{Cy}$, cytochrome $c, 12.8 \mathrm{kDa}, \mathrm{pI}$ 9.8). $(b, c)$ Activity stain of tyrosinase; $(d, e)$ autoradiography of labelled proteins. $(b, d)$ Samples of protein from cells non-induced by copper; $(c, e)$ Samples of protein from copper-induced cells. Cells were grown in $\mathrm{SM}+$ arginine. After $46 \mathrm{~h}\left[{ }^{35} \mathrm{~S}\right] \mathrm{methionine}$ and $\mathrm{Cu}^{2+}$ were added. At $0 \mathrm{~h}$ (lane 1), 1.2 h (lane 2), $2.7 \mathrm{~h}$ (lane 3), $4.7 \mathrm{~h}$ (lane 4), $6.2 \mathrm{~h}$ (lane 5) and $7.7 \mathrm{~h} \mathrm{(lane} \mathrm{6)} \mathrm{the} \mathrm{cells} \mathrm{were} \mathrm{sampled,} \mathrm{disrupted}$ and the proteins $(20 \mu \mathrm{g}$ per slot) were electrophoretically separated on a native acidic polyacrylamide gel $(12 \cdot 5 \%$, w/v). After activity staining with 3,4-dihydroxy-L-phenylalanine to locate the tyrosinase band, the gel was exposed to an autoradiography film for $10 \mathrm{~d}$. 


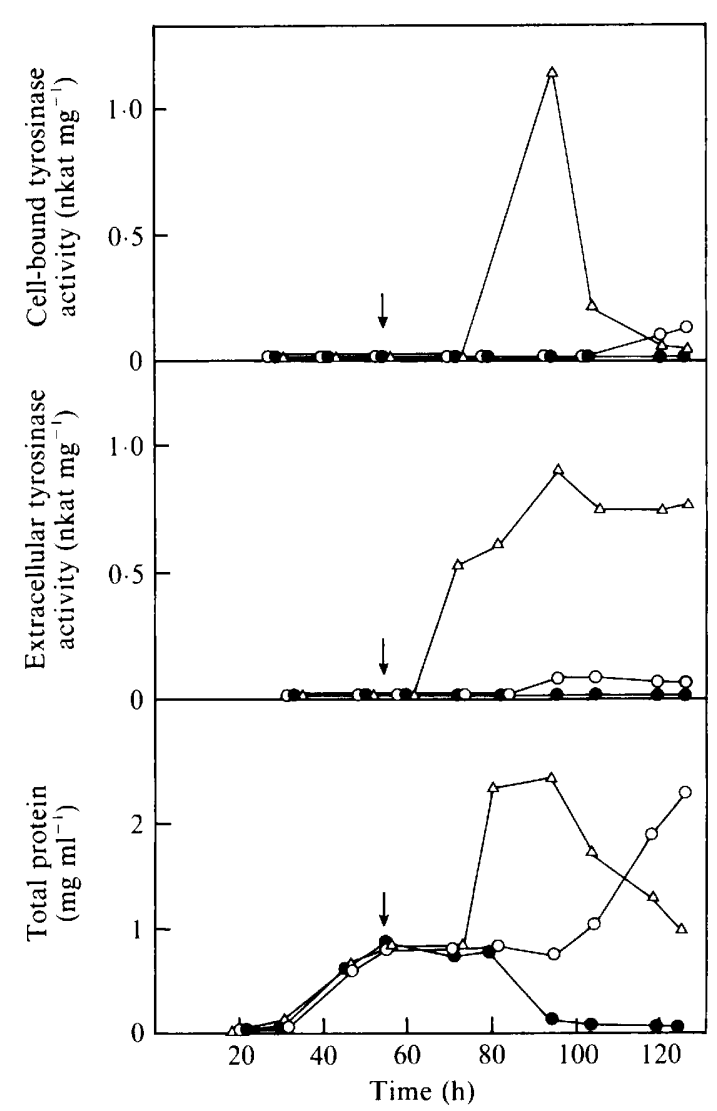

Fig. 6. Removal of ammonium repression. Three cultures were grown

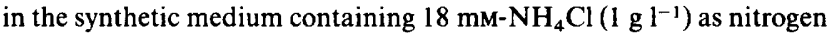
source. After $54 \mathrm{~h}$ (arrows) the flasks were treated as follows: addition of $\mathrm{CuSO}_{4}\left(10^{-4} \mathrm{M}\right.$ final concn); $\mathrm{O}$, addition of $\mathrm{CuSO}_{4}\left(10^{-4} \mathrm{M}\right)$ and arginine ( $5 \mathrm{~g} \mathrm{l}^{-1}$ final concn); $\triangle$, the culture was harvested by centrifugation and transferred into synthetic medium containing arginine $\left(5 \mathrm{~g} \mathrm{l}^{-1}\right)$ and $\mathrm{CuSO}_{4}\left(10^{-4} \mathrm{M}\right)$.

copper alone had no effect, when both copper and arginine were added an increase of tyrosinase formation and a second growth phase occurred after a long lag phase of about $40 \mathrm{~h}$. However, harvesting and transfer of ammonium-grown mycelium into synthetic medium containing arginine and copper caused a dramatic increase in both tyrosinase formation and growth within only $5 \mathrm{~h}$.

The repression of tyrosinase biosynthesis depended on the concentration of ammonium in the medium (Fig. 7): with $4 \mathrm{mM}^{-\mathrm{NH}_{4}^{+}}$only about two-thirds of the control activity $\left(0 \mathrm{~mm}-\mathrm{NH}_{4}^{+}\right)$was obtained. $10 \mathrm{~mm}-\mathrm{NH}_{4}^{+}$repressed tyrosinase formation almost completely.

\section{DNA dot-blot hybridization}

DNA dot-blot hybridization of pTH-cif and pTH-tyr with different dilutions of total DNA $(1.6 \mu \mathrm{g}$ to $0.04 \mu \mathrm{g})$ isolated from $S$. michiganensis, $S$. antibioticus and $S$. lividans was carried out at a stringency of $73 \%$ (data not

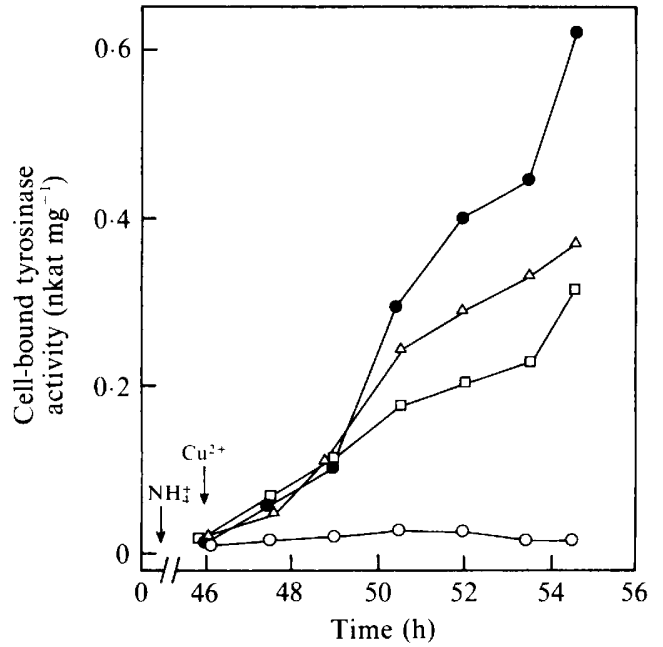

Fig. 7. Repression of tyrosinase formation as a function of the concentration of $\mathrm{NH}_{4}^{+}$. The cells were cultivated for $45 \mathrm{~h}$ in the synthetic medium + arginine. $\mathrm{NH}_{4}^{+}$was added $1 \mathrm{~h}$ before induction by $\mathrm{Cu}^{2+}\left(10^{-4} \mathrm{M}\right.$ final concn). $\bigcirc, 10 \mathrm{mM}-\mathrm{NH}_{4}^{+} ; \square, 6 \mathrm{mM}-\mathrm{NH}_{4}^{+} ; \Delta, 4 \mathrm{~mm}-$ $\mathrm{NH}_{4}^{+} ; \bullet, 0$ mM-NH$H_{4}^{+}$.

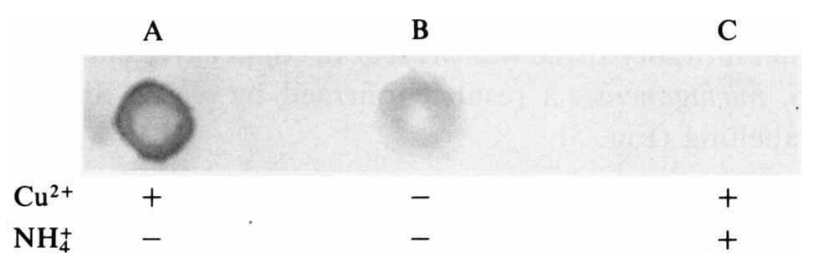

Fig. 8. Hybridization of the probe pTH-mel with RNA isolated from $S$. michiganensis (RNA dot blot). The cells were pregrown for $46 \mathrm{~h}$ in the synthetic medium + arginine. Ammonium repression was then carried out, where indicated, by addition of $10 \mathrm{~mm}-\mathrm{NH}_{4}^{+}$(final concn). Induction with copper was carried out, where indicated, at $47 \mathrm{~h}$ $\left(10^{-4} \mathrm{M}\right.$, final concn). All cultures were harvested after $51 \mathrm{~h}$. RNA was prepared from cells of: A, copper-induced, ammonium-non-repressed cultures; B, copper-non-induced, ammonium-non-repressed cultures; $\mathrm{C}$, copper-induced, ammonium-repressed cultures.

shown). Both probes gave signals with the DNA from the melanin-producing $S$. antibioticus (positive control), and the DNA from $S$. michiganensis. No signal could be obtained with the DNA of $S$. lividans (negative control, melanin-negative). The specificity of the probes was proved by demonstrating that the SalI fragment of the tyrosinase structural gene cloned into pTH-tyr did not hybridize with the sequence of $\mathrm{ORF}_{438}$ at the level of $73 \%$ homology (not shown). Based on this result it is evident that $S$. michiganensis possesses a gene related to $\mathrm{ORF}_{438}$.

\section{RNA dot-blot hybridization}

After proving the specific hybridization of pTH-mel with total DNA isolated from $S$. michiganensis, this probe was used for dot-blot experiments (Fig. 8). While 
hybridization with RNA isolated from copper-induced, ammonium-non-repressed cells gave a strong signal (a), only a weak signal could be obtained with RNA from copper-non-induced, ammonium-non-repressed cells $(b)$. No signal could be found using RNA from copperinduced, ammonium-repressed cells (c). These results show that both copper induction and ammonium repression of tyrosinase production occur at the level of transcription, and that ammonium-repressed tyrosinase biosynthesis cannot be induced by copper.

\section{Discussion}

Since tyrosinase contains copper in its active site, the necessity of this metal for the formation of the active enzyme is obvious. Lee et al. (1988) were able to partially reactivate apotyrosinase, prepared by $\mathrm{KCN}$ treatment, by adding low concentrations of copper. In our experiments no increase in tyrosinase activity occurred upon addition of copper to crude extracts and culture filtrates of $S$. michiganensis grown without copper. This indicated that no apotyrosine was present in copper-free cultures of $S$. michiganensis a result confirmed by $\left.{ }^{[3} \mathrm{S}\right]$ methionine labelling (Fig. 5).

Hybridization experiments revealed that a gene related to the $S$. antibioticus $\mathrm{ORF}_{438}$ (whose gene product is probably responsible for the incorporation of copper into apotyrosinase; Lee et al., 1988) might be present in $S$. michiganensis. In adddition, genetical and protein chemical data (unpublished) of the tyrosinase of this species are in agreement with corresponding data for the tyrosinase of $S$. glaucescens; it therefore appears that the genetics and biosynthesis of tyrosinase are similar in $S$. glaucescens, $S$. antibioticus and $S$. michiganensis although the tyrosinase of $S$. michiganensis is not inducible by Lmethionine. Assuming for $S$. michiganensis the same gene arrangement as in $S$. glaucescens and $S$. antibioticus, i.e. the formation of a polycistronic mRNA containing $\mathrm{ORF}_{402}$ or $\mathrm{ORF}_{438}$ respectively and the structural gene of the tyrosinase, it seems reasonable that in $S$. michiganensis copper induces the tyrosinase structural gene as well as the copper-incorporation factor and possibly in addition a regulatory cell-bound copperbinding protein.

Nitrogen regulation is a common phenomenon among bacteria (Kleiner, 1984). In Streptomyces the formation of a large number of antibiotics is regulated by ammonium (Kleinkauf $e t$ al., 1986). In this study it was shown that ammonium repressed the formation of tyrosinase and actinomycin in $S$. michiganensis. The addition of arginine to liquid cultures of $S$. michiganensis grown with $\mathrm{NH}_{4} \mathrm{Cl}$ is followed by tyrosinase biosynthesis as well as by increased growth although only after a long lag phase. This suggests that the metabolism of arginine is also repressed as long as $\mathrm{NH}_{4} \mathrm{Cl}$ is present in the medium: metabolism of arginine and tyrosinase biosynthesis started only after the ammonium in the medium was exhausted. Furthermore it was shown by several experiments in this study (Figs 6,7 and 8) that ammonium-repressed tyrosinase formation could not be induced by addition of copper; therefore the ammonium repression might be an overriding mechanism of enzyme regulation. We isolated three ammonium-derepressed mutants (amd; MIC150, MIC153, MIC154) by plating NTG-mutagenized spores on synthetic medium containing tyrosine $\left(1 \mathrm{~g} \mathrm{l}^{-1}\right), \mathrm{CuSO}_{4}\left(10^{-4} \mathrm{M}\right)$ and $\mathrm{NH}_{4} \mathrm{Cl}$ $\left(1 \mathrm{~g}^{-1}\right)$ as nitrogen source. Since none of the mutants were very stable, only preliminary tests could be carried out. Agar plate tests showed that tyrosinase and actinomycin were formed by mutants MIC150 and MIC153 on medium containing ammonium as sole nitrogen source. MIC154 synthesized only tyrosinase on this medium. Mutants MIC150 and MIC154 did not form aerial mycelium. Since the ammonium repression of the formation of both tyrosinase and actinomycin occurred at the level of transcription, as shown by hybridization experiments, and since both effects could be abolished in mutants MIC150 and MIC153, a pleiotropic intracellular effector mediating nitrogen control via nitrogen-regulated promotors might be responsible for this effect. According to this model, MIC154, which is derepressed only in tyrosinase formation, might be a promoter mutant.

The senior author of this paper acknowledges the receipt of a BMFT Biotechnology Fellowship of the Deutsche Gesellschaft für Chemisches Apparatewesen, Chemische Technik und Biotechnologie eV, Frankfurt.

\section{References}

BaumanN, R. \& KoCher, H. P. Genetics of Streptomyces glaucescens and regulation of melanin production. In Genetics of Industrial Microorganisms, pp. 535-551. Edited by K. D. Macdonald. London: Academic Press.

Bernan, V., Filpula, D., Herber, W., Bibb, M. \& Katz, E. (1985). The nucleotide sequence of the tyrosinase gene from Streptomyces antibioticus and characterization of the gene product. Gene 37, 101110.

BIRnBoim, H. C. \& Doly, J. (1979). A rapid alkaline extraction procedure for screening recombinant plasmid DNA. Nucleic Acids Research 7, 1513-1522.

BLACKSHEAR, P. J. (1984). Systems for polyacrylamide gel electrophoresis. Methods in Enzymology 104, 237-255.

BRADFORD, M. M. (1976). A rapid and sensitive method for the quantitation of microgram quantities of protein utilizing the principle of protein-dye binding. Analytical Biochemistry 72, 248254.

Chirgwin, J. M., Przybyla, A. E., MacDonald, R. J. \& Rutter, W. J. (1979). Isolation of biologically active ribonucleic acid from sources enriched in ribonuclease. Biochemistry 18, 5294-5299. 
Crameri, R., Ettlinger, L., HÜtter, R., LerCh, K., Suter, M. A. \& VetTERLI, J. A. (1982). Secretion of tyrosinase in Streptomyces glaucescens. Journal of General Microbiology 128, 371-379.

Drews, G. (1983). Mikrobiologisches Praktikum. Berlin, Heidelberg \& New York: Springer.

FUCHS, R. \& BLAKESLEY, R. (1983). Guide to the use of type II restriction endonucleases. Methods in Enzymology 100, 3-38.

Hopwood, D. A., BibB, M. J., Chater, K. F., Kieser, T., Bruton, C. J., Kieser, H. M., Lydiate, D. J., SMith, C. P., Ward, J. M. \& SCHREMPF, H. (1985). Genetic Manipulation of Streptomyces - a Laboratory Manual. Norwich: John Innes Foundation.

HUBER, M. \& LERCH, K. (1988). Identification of two histidines as copper ligands in Streptomyces glaucescens tyrosinase. Biochemistry 27, 5610-5615.

Huber, M., Hinterman, G. \& LeRCh, K. (1985). Primary structure of tyrosinase from Streptomyces glaucescens. Biochemistry 24, 60386044.

Jerumanis, J., Van HuYnh, N. \& Devreux, A. (1976). Determination and properties of barley and malt phenoloxidase. Journal of the American Society of Brewery Chemistry 34, 38-43.

KATZ, E. \& BETANCOURT, A. (1988). Induction of tyrosinase by Lmethionine in Streptomyces antibioticus. Canadian Journal of Microbiology 34, 1297-1303.

Katz, E., Thompson, C. J. \& Hopwood, D. A. (1983). Cloning and expression of the tyrosinase gene from Streptomyces antibioticus in Streptomyces lividans. Journal of General Microbiology 129, 27032714.
KIESER, T., EtTlingeR, L. \& HÜTTER, R. (1976). Mutants of Streptomyces glaucescens constitutive for tyrosinase synthesis. In Genetics of Actinomycetales, pp. 59-60. Edited by E. Freerksen, I. Tárnok \& J. H. Thumin. Stuttgart \& New York: Gustav Fischer. KLEINER, D. (1984). Bakterien und Ammonium. Forum Mikrobiologie 7, 13-19.

Kleinkauf, H., Döhren, H., Dornauer, H. \& Nesemann, G. (1986). Regulation of Secondary Metabolite Formation. Weinheim: VCH Verlagsgemeinschaft.

LEE, Y.-H. W., ChEN, B.-F., Wu, S.-Y., LeU, W.-M., LIN, J.-J., CheN, C. W. \& Lo, S. J. (1988). A trans-acting gene is required for the phenotypic expression of a tyrosinase gene in Streptomyces. Gene 65 , 71-81.

LeRCH, K. \& ETtLINGeR, L. (1972). Purification of a tyrosinase from Streptomyces glaucescens. European Journal of Biochemistry 31, 427437.

Maniatis, T., Fritsch, E. F. \& Sambrook, J. (1982). Molecular Cloning - a Laboratory Manual. Cold Spring Harbour, NY: Cold Spring Harbour Laboratory.

Platen, H. \& Kutzner, H. J. (1986). Einfluss von Kupfer auf Wachstum und Tyrosinase-Aktivität von Streptomyceten. VDLUFA Schriftenreihe 20, Kongressband, 859-869.

Yanisch-PerRon, C., Vieira, J. \& Messing, J. (1985). Improved M13 phage cloning vectors and host strains: nucleotide sequences of the M13mp18 and pUC19 vectors. Gene 33, 103-119. 